\title{
Protecting societal interests in corporate takeovers
}

\author{
Citation for published version (APA):
}

Ai, H. (2021). Protecting societal interests in corporate takeovers: A comparative analysis of the regulatory framework in the U.K., Germany and China. [Doctoral Thesis, Maastricht University]. ProefschriftMaken. https://doi.org/10.26481/dis.20211208ha

Document status and date:

Published: 01/01/2021

DOI:

10.26481/dis.20211208ha

Document Version:

Publisher's PDF, also known as Version of record

\section{Please check the document version of this publication:}

- A submitted manuscript is the version of the article upon submission and before peer-review. There can be important differences between the submitted version and the official published version of record.

People interested in the research are advised to contact the author for the final version of the publication, or visit the DOI to the publisher's website.

- The final author version and the galley proof are versions of the publication after peer review.

- The final published version features the final layout of the paper including the volume, issue and page numbers.

Link to publication

\footnotetext{
General rights rights.

- You may freely distribute the URL identifying the publication in the public portal. please follow below link for the End User Agreement:

www.umlib.nl/taverne-license

Take down policy

If you believe that this document breaches copyright please contact us at:

repository@maastrichtuniversity.nl

providing details and we will investigate your claim.
}

Copyright and moral rights for the publications made accessible in the public portal are retained by the authors and/or other copyright owners and it is a condition of accessing publications that users recognise and abide by the legal requirements associated with these

- Users may download and print one copy of any publication from the public portal for the purpose of private study or research.

- You may not further distribute the material or use it for any profit-making activity or commercial gain

If the publication is distributed under the terms of Article $25 \mathrm{fa}$ of the Dutch Copyright Act, indicated by the "Taverne" license above, 


\section{SUMMARY}

Corporate takeovers may have positive as well as negative effects on the different stakeholders involved. This thesis addressed the question "What are the societal interests that may be affected by a takeover, are these protected under the current regulatory frameworks of the U.K., Germany and China; (and if so) how are they protected and what recommendations can be made for future reforms in the three jurisdictions?" To answer this research question, the thesis discussed four sub-questions: (1) What market failure(s) can be caused by a takeover and what kinds of societal interests are affected? (2) What are the relevant societal interests that are currently regulated in the three jurisdictions and which protection mechanisms are used? (3) What are the similarities and differences between the regulatory frameworks of the three jurisdictions, and what are the strengths and weaknesses of these frameworks in addressing the relevant market failure(s) and protecting societal interests in takeovers? (4) Based on the strengths and weaknesses of the current regulatory frameworks and protection mechanisms, what recommendations can be made for future reforms in the three jurisdictions? The main research findings of the thesis are as follows:

1. Market failures may arise as a result of takeovers and affect the "relevant societal interests", which include (1) the interests of corporate stakeholders, (2) the legally recognized public interest considerations, and (3) other societal interests affected by a takeover.

Chapter 1 provided preliminary definitions of the concepts "relevant stakeholders" and "relevant societal interests" and made the presumption that "a takeover may affect a wide range of societal interests". Chapter 2 conducted an economic analysis and found that four types of market failures may arise as a result of takeovers: increase of market power (potential monopoly), severe information asymmetries, negative externalities, and undersupply of public goods. It also observed that the market failure problems may affect three types of societal interests: (1) the interests of corporate stakeholders with whom target companies have a contractual relationship, (2) the 
legally recognized public interest considerations, and (3) other societal interests affected by a takeover. This finding responded to the presumption in Chapter 1 and illustrated the importance of protecting the relevant societal interests in takeovers by government regulation and private regulation.

2. Public laws (competition law and FDI screening laws) in the three jurisdictions recognize and protect certain public interest considerations in takeovers; private laws (takeover law and corporate law) and national corporate governance codes in the three jurisdictions mainly protect the interests of corporate stakeholders (primarily the shareholders) and other societal interests affected by a takeover.

Chapters 3 to 5 examined the government regulation (including public laws such as the competition law and FDI screening regulations, and private laws such as the takeover law and corporate law) and private regulation (mainly the national corporate governance code) in the U.K., Germany and China respectively. Each of the three chapters explored the three types of societal interests that are protected by the public laws, private laws and the national corporate governance codes and the specific protection mechanisms. Chapter 6 conducted a comparison of the protection mechanisms in the three jurisdictions and discussed the strengths and weaknesses of these regulatory frameworks in solving the market failure(s) relating to different societal interests.

The thesis found that public laws (competition law and FDI screening laws) in the three jurisdictions all recognize and protect certain public interest considerations in takeovers. The competition laws in the three jurisdictions address the market failure of market power and protect the competition interest through merger control rules. Meanwhile, they incorporate a "public interest intervention" (as in the EA 2002 of the U.K.) or "public interest exemption" mechanism (as in the GWB of Germany and in the AML of China) to deal with negative externalities, severe information asymmetries and undersupply of public goods and protect other public interest considerations. The EA 2002 of the U.K. recognizes four types of public interest considerations in takeovers: the national security interest, the public interest considerations relevant to newspaper and media mergers, the stability of the financial 
market, and the capability of the country in combating and mitigating public health emergencies (added in 2020 to respond to the COVID-19 pandemic). By comparison, the "public interest exemption" mechanisms in the GWB of Germany and in the AML of China are formulated in general provisions and do not provide for explicit public interest considerations.

In the FDI screening regime, the three jurisdictions all provide for a national security review mechanism for foreign takeovers. In China, in addition to the security review, there is more complex market access regulation and administrative regulation of foreign takeovers compared to the U.K. and Germany. After a series of major reforms in recent years, currently, the national security review in the three jurisdictions addresses not only negative externalities on the commonly recognized defence interest and shortage in the supply of public goods (national defence), but also regulates an increasing number of other societal interests in the name of protecting the security interest of the country. In 2020, to respond to the COVID-19 pandemic, the three jurisdictions significantly enlarged the scope of sectors and activities that are deemed as relating to the "security interest" in foreign takeovers and subject to a security review.

The thesis also observed that takeover laws of the three jurisdictions, through the rules that restrict the board of directors' anti-takeover measures and rules that require the acquirer and target board to disclose information about the takeover offer, directly regulate the negative externalities and severe information asymmetries relating to target shareholders. Apart from shareholder protection, takeover laws in the U.K. and Germany also address severe information asymmetries relating to other stakeholders by requiring the acquirer company and target board(s) to disclose the anticipated consequences of the takeover to other stakeholders. The Chinese takeover law lacks such disclosure requirement relating to other stakeholders. Moreover, compared with the takeover laws in Germany and China, takeover law in the U.K. provides more direct protection to other stakeholders by the "post-offer undertaking" and "post-offer intention statement" mechanism. Corporate governance mechanisms in the three jurisdictions do not regulate specific public interest considerations. They only play a 
marginal role in addressing the negative externalities and severe information asymmetries relating to the interests of corporate stakeholders and other societal interests affected by a takeover.

\section{Based on the strengths and weaknesses of the current regulatory frameworks} of the three jurisdictions, the thesis provides three recommendations for future reforms in the U.K., Germany and China.

Chapter 7 summarized the answers to Sub-questions 1 to 3 and gave recommendations for future reforms in the three jurisdictions. The thesis provided the argument that apart from the legally recognized public interest considerations in the current competition laws and FDI screening laws of the three jurisdictions, other societal interests which in the past were not recognized by these public laws as belonging to the "public interest" may become of crucial importance in emerging takeovers and have a wide impact on the public at large. Chapter 7 brought forward two main factors the three jurisdictions should take into account when deciding whether to modify their public laws to recognize new societal interests as public interest considerations in takeovers in the future: (1) the impact of the relevant societal interests on society; (2) whether the private laws already contain mechanisms or have the potential to be modified to protect these societal interests. Chapter 7 proposed that the three jurisdictions should modify their takeover law to either introduce new mechanisms (in Germany and China) or strengthen the existing mechanisms (in the U.K.) to incentivize the acquirer to consider other stakeholders of the target in a takeover. As to the corporate governance regime, the thesis holds that the three jurisdictions should introduce new corporate governance mechanisms to incentivize the target company to more seriously consider the interests of non-shareholder corporate stakeholders and other societal interests affected by a takeover. The main recommendations the thesis provides are as follows:

Recommendation 1: Expansion of the recognized public interest considerations in the competition law and FDI screening laws should be conducted cautiously and should follow the principles of "necessity" and "proportionality".

Recommendation 2: With regard to the takeover law regime of Germany and China, 
these jurisdictions can learn from the U.K. by introducing mechanisms to incentivize the acquirers to make arrangements for stakeholders, and the U.K. should reinforce the implementation of the current "post-offer undertaking" and "post-offer intention statement" mechanisms.

Recommendation 3: In the three jurisdictions, future reforms in the corporate governance regime should work towards incentivizing the board to introduce more engagement mechanisms for non-shareholder stakeholders, and towards incentivizing the shareholders to better take into account other stakeholders' interests in their decisions and to disclose their engagement policy in the company with regard to the stakeholder matters. 